\begin{tabular}{|c|l|}
\hline Title & $\begin{array}{l}\text { Vertical distribution of amino acids and chiral ratios in deep sea hydrothermal sub-vents of the Suiyo Seamount, Izu- } \\
\text { Bonin A rc, Pacific Ocean }\end{array}$ \\
\hline Author(s) & Takano, Y oshinori; Horiuchi, Tsukasa; Marumo, Katsumi; Nakashima, Miwako; U rabe, Tetsuro; Kobay ashi, Kensei \\
\hline Citation & $\begin{array}{l}\text { Organic Geochemistry, 35(10), 1105-1120 } \\
\text { https://doi.org/40.1016j.orggeochem.2004.06.007 }\end{array}$ \\
\hline Issue Date & 2004_10 \\
\hline Doc URL & http://hdl.handle.net/2115/48298 \\
\hline Type & article(author version) \\
\hline File Information & Takano_OG2004_HUSCAP.pdf \\
\hline
\end{tabular}

Instructions for use 


\section{Vertical distribution of amino acids and chiral ratios in deep-sea hydrothermal sub-vents of the Suiyo Seamount, Izu-Bonin Arc, Pacific Ocean}

Yoshinori Takano ${ }^{1,2 *}$, Tsukasa Horiuchi ${ }^{2}$, Katsumi Marumo ${ }^{1}$, Miwako Nakashima ${ }^{1}$, Tetsuro Urabe ${ }^{3}$, and Kensei Kobayashi ${ }^{2}$

${ }^{1}$ Institute for Marine Resources and Environment, National Institute for Advanced Industrial Science and Technology (AIST), AIST Central 7, 1-1-1 Higashi, Tsukuba, Ibaraki 305-8567, Japan

${ }^{2}$ Department of Chemistry and Biotechnology, Yokohama National University, 79-5 Hodogaya-ku, Yokohama 240-8501, Japan

${ }^{3}$ Department of Earth and Planetary Science, University of Tokyo, 7-3-1 Hongo, Bunkyo-ku, Tokyo 113-0033, Japan

15

*Corresponding author: Yoshinori Takano

Institute for Marine Resources and Environment,

National Institute for Advanced Industrial Science and Technology (AIST),

20 AIST Central 7, 1-1-1 Higashi, Tsukuba, Ibaraki 305-8567, Japan

Tel: +81-29-861-3638, Fax: Tel: +81-29-861-3638

(E-mail: takano.yoshinori@aist.go.jp) 


\section{Abstract}

A high-temperature deep-sea hydrothermal system related to dacitic arc-volcanism has been drilled using a tethered, submarine rock-drill system as a part of the Archaean Park Project. The benthic multi-coring system (BMS) employed allows for direct sampling of microorganisms, rocks and fluids beneath hydrothermal vents. The samples examined in this study are from sites APSK 08, 09 and 10 on the Suiyo seamount of the Izu-Bonin Arc in the Pacific Ocean. Based on the vertical distribution and stereochemistry of amino acids in this vigorous sub-vent environment, a model of deep-sea subterranean chemistry and biology is proposed, describing optimal microbial activities rather than abiotically synthesized amino acids components. Total hydrolyzed amino acids in the hydrothermal sub-vent core samples are on the order of $10^{1}-10^{2} \mathrm{nmol} / \mathrm{g}$-rock. The ratios of $\beta$-alanine/aspartic acid and $\gamma$-aminobutyric acid/glutamic acid are low, consistent with a large microbial population and fresh subterranean bioorganic compounds. The $\mathrm{D} / \mathrm{L}$ ratios of chiral amino acids such as aspartic acid, glutamic acid and alanine in these rock samples were also quite low overall. Large enantiomeric excesses of L-form amino acids also support the existence of a vigorous subjacent microbial oasis in this seamount hydrothermal sub-system.

40 The present findings represent crucial evidence that sub-vent regions are a previously unknown extreme-environment biosphere, extending the known subterranean habitable spaces.

Keywords: deep-sea hydrothermal sub-vent, amino acids, stereo chemistry, 45 subterranean biosphere 


\section{Introduction}

Deep-sea hydrothermal systems are natural laboratories for the study of organic geochemistry regarding microbial habitats on extreme environments. The historical discovery of the Galapagos deep-sea hydrothermal systems (Corliss et al., 1979) has lead many researchers to consider that deep-sea hydrothermal systems are suitable environments for chemical evolution, with possible implications for the origins of life on Earth (e.g. Holm, 1992). The extremophilic phenomena of these environments have attracted interest from many scientific viewpoints, including geology, oceanography, biology, chemistry and physics (e.g. Holm, 1992). Anomalous concentrations of glycine in the Red Sea may also support the notion of deep-sea chemical evolution and biogeochemistry (Ingmanson et al., 1980). In fact, a number of submarine ecological colonies have been recognized near black or clear smokers and the associated organic-rich seafloor mats (Gold, 1992; Craggs and Parkes, 1994).

The biological environment of extreme ocean-floor vents can be well characterized by bioorganic compounds, particularly amino acids, which are common components of all organisms and constitute a major fraction of organics (Henrichs and Farrington, 1979). There have been several reports dealing with amino acid distributions in surface sediments of coastal regions (Shimoyama and Ponnamperuma, 1975; Burdige 65 and Martens, 1988, 1990; Cowie and Hedges, 1994; Henrichs and Farrington, 1987; Burdige, 2001), of deep-sea sediment (Henrichs et al., 1984; Horsfall and Wolff, 1997; Rittenberg et al., 1963; Whelan, 1977), and in deep-sea sediment cores (Aizenshtat et al., 1973; Bada and Man, 1980). However, the amino acid distributions in deep-sea sediments from areas of hydrothermal activity have been studied at only a few locations.

70 For example, Haberstroh and Karl (1989) investigated the total dissolved free amino acid concentrations in high-temperature smoker fluids and in interstitial waters of sediments recovered from a sediment-covered hydrothermal vent system located in the southern Guaymas Basin, Gulf of California; Silfer et al. (1990) isolated the water- and acid-extractable amino acid fractions of sediments affected by hydrothermal processes in the Bransfield Strait, Antarctic Peninsula; and Kawahata and Ishizuka (1989) determined the vertical distribution of amino acids in interstitial waters of ridge-flank sediments from the Galapagos spreading center.

Sub-vents, subjacent to seafloor hydrothermal vents, are of significant interest as a 
new scientific frontier (Urabe et al., 2001). While the existence of a deep bacterial biosphere in oceanic sediment has been reported (e.g. Parkes et al., 1994: Fredrickson and Fletcher, 2001), the hydrothermal sub-vent world has yet to be described. The purpose of this study is to investigate the vertical distribution and stereochemistry of amino acids in deep-sea sediments affected by low- to high-temperature hydrothermal activity. The samples analyzed in this study are deep-sea sediments recovered from the subjacent hydrothermal system of the Suiyo seamount, Izu-Bonin Arc, Pacific Ocean.

Amino acids associated with life, particularly those in proteins, exist as L-form only, that is, chiral. The process of amino acid racemization in various geochemical samples from terrestrial (e.g. Takano et al., 2003b) and marine environments (e.g. Harada and

90 Handa, 1995) has been widely applied in geochemical research. Racemization of amino acids is primarily dependent on the age and temperature of the environment (Bada and Schroeder, 1975). As racemization in hydrothermal environments is expected to progress via kinetic control based on environmental temperature (Bada, 1972), the $\mathrm{D} / \mathrm{L}$ ratios of samples can be used as indicators of the extent of organic matter alteration and the coincidence of subterranean microbial activity.

In the present study, the D-form and L-form contents of aspartic acid (Asp), glutamic acid (Glu), and alanine (Ala) together with absolute and relative concentrations of 17 hydrolyzed amino acids were determined in core samples from a deep-sea hydrothermal sub-vent on the Suiyo seamount. This report describes the vertical distribution and stereochemistry of amino acids under these extreme conditions, leading to a model of deep-sea subterranean chemistry and biology. The chemical aspects of abiotic synthesis of amino acids (e.g. Yanagawa and Kobayashi, 1988; Islam et al., 2001) and their oligomerization processes (e.g. Imai et al., 1999; Islam et al., 2003) have been investigated using simulated submarine hydrothermal systems, and the 105 stereochemistry of amino acids is of notable interest in the process of chemical evolution (Takano et al., 2001;Takano et al., 2002). Biologically, however, it is considered that hyperthermophiles (e.g. Blochl et al., 1997) or barophiles with affinity for high pressure (e.g. Prier, 1992) are likely to be widespread in regions immediately below hydrothermal vents. 


\section{Geological location and hydrothermal fluid discharge}

The Izu-Bonin Arc lies on the eastern rim of the Philippine Sea plate. This arc is about 1,200 km long, extending from the Izu Peninsula $\left(35^{\circ} \mathrm{N}, 139^{\circ} \mathrm{E}\right)$ to Minami-Iwojima Island $\left(24^{\circ} \mathrm{N}, 141^{\circ} \mathrm{E}\right)$. This arc belongs to the circum-Pacific

115 island-arc system and is adjacent to the Northeast Japan Arc to the north and the Mariana Arc to the south. Many volcanic islands and submarine volcanoes run parallel to the Izu-Bonin trench and form the volcanic front of this intra-oceanic island-arc system. The southern Izu-Bonin Arc, which is divided by the Sofugan tectonic line from the northern Izu-Bonin Arc (Tsunogai et al., 1994) (Fig. 1-a), is

120 thought to have become active at around $42 \mathrm{Ma}$ (Yuasa, 1992). The Shichiyo seamount chain forms a volcanic front (Fig. 1-b) around which the arc crust is inferred to become thinner than that in the northern part (Hino, 1991). The Suiyo Seamount, one of the volcanoes in the Shichiyo chain, has two major peaks, located on the eastern and western sides of the seamount. The Suiyo Seamount is an active submarine volcano, and vigorous hydrothermal activity has occurred on the caldera floor atop the west peak (Watanabe and Kajimura, 1994; Yuasa et al., 1991). Dacitic rocks of a calc-alkaline rock series and low-potassium andesites have been recovered from this area (Watanabe and Kajimura, 1993), and seafloor hydrothermal alteration at Suiyo has been preliminarily reported from the point of view of geochemical and mineralogical 130 characteristics (Marumo et al., 2002; Marumo et al., 2003; Marumo et al., 2004).

As to terrestrial origin of organics on Suiyo seamount, it was reported that total fatty acid compositions in surface sediments obtained from Suiyo hydrothermal system, Izu-Bonin Arc were not significant components of sedimentary organic matter (Yamanaka et al., 2001; Yamanaka and Sakata, 2004). Analytical results of the 135 surface sediments indicated very low contributions of terrestrial sediments. In addition, age determination of unaltered dacite by Ar-Ar method yields 9,000 \pm 8,000 yrBP, suggesting zero age (Marumo et al., 2003; Marumo et al., 2004). The caldera floor is predominantly covered with sandy sediment and hydrothermal precipitations and lacks any evidence of muddy pelagic sediment.

140 The vertical variations in the mineral assemblages of these cores are presented in Figure 2. The core profile is characterized by dacitic lava and/or pyroclastic rocks at 
the surface underlying unconsolidated volcanic sands and pumice fragments; a sheath of clay minerals and anhydrite cement with minor pyrite and other sulfide minerals that acts as a cap rock of the geothermal system; and end-member fluid ponding beneath the sheath. Extensive hydrothermal alteration is observed in the sedimentary unit and the upper fraction of the volcanic rocks. Numerous short black smokers and clear smokers were observed on the sandy floor. Hydrothermal circulation reaches the region adjacent to the magma source, and volatile constituents are extracted by water-rock interaction (Urabe et al., 2001; Urabe et al., 2003).

150

\section{Experimental}

\section{Sampling}

The deep-sea hydrothermal sub-vent core samples were collected as part of the Archaean Park Project in a cruise over the Suiyo Seamount (28 $33^{\prime}$ N, $140^{\circ} 39^{\prime}$ E) in

155 the Pacific Ocean in June, 2002. The deep-sea subterranean biosphere and geochemical interaction were examined by taking core samples using a fixed seafloor benthic multi-coring system (BMS) for pinpoint drilling in the caldera (Urabe et al., 2001). The maximum depth of coring at sites APSK 08, 09 and 10 were $3.807 \mathrm{~m}$, $7.035 \mathrm{~m}$ and $8.993 \mathrm{~m}$ below the sea floor, respectively. The hydrothermal fluid

160 temperature measured using a custer-type thermometer (Ikeuchi et al., 1998) was $69.2^{\circ} \mathrm{C}$ at APSK 08 , and $89.3^{\circ} \mathrm{C}$ at APSK 10. The fluid temperature at APSK 09 could not be measured.

\section{Extraction of amino acids}

165 Rock core samples were carefully obtained and quickly sealed with a pack of dehydrating and deoxygenation reagent (AGELESS, Mitsubishi Gas Chemicals Co.). The sample was powdered and freeze-dried. Then, ca. $1.00 \mathrm{~g}$ of the sample was placed in a Teflon tube that had been cleaned by soaking it in $7 \mathrm{M} \mathrm{HNO}_{3}$ overnight and rinsed in Milli-Q-water (Millipore Corp.). $10 \mathrm{ml}$ of $5 \mathrm{M} \mathrm{HF}-0.1 \mathrm{M} \mathrm{HCl}$ mixture was poured 170 in the Teflon tube, which was placed in a metal holder. It was continuously heated at $110{ }^{\circ} \mathrm{C}$ for 16 hours in order to release organics from the silicate matrix. After HF-HCl degradation, Teflon tubes were placed on a hot plate in a draft chamber to evaporate acids. The organic residues were extracted with pure water with 
ultra-sonication. The aqueous fraction was filtered with a GF/A 1.6 $\mu \mathrm{m}$ glass filter, and then freeze-dried in a glass test tube. $2 \mathrm{ml}$ of $6 \mathrm{M} \mathrm{HCl}$ was added to each of the test tubes to obtain total hydrolyzed amino acid fraction (THAA). The test tube was sealed and placed in a block heater and heated for 2 hours at $110{ }^{\circ} \mathrm{C}$. The hydrolysates were then dried in vacuo using a diaphragm pump. After dryness, the portions were adjusted to $\mathrm{pH} 1$ with $0.1 \mathrm{M} \mathrm{HCl}$, followed by desalting with a AG-50W-X8 (200-400 mesh) cation exchange resin column (Bio-Rad Lab.). Before application of the sample to the column, the resin had been cleaned by passing $1 \mathrm{M} \mathrm{HCl}, \mathrm{H}_{2} \mathrm{O}, 1 \mathrm{M} \mathrm{NaOH}$ and $\mathrm{H}_{2} \mathrm{O}$ successively through the column. Just before applying the sample the resin was reactivated with $10 \mathrm{ml}$ of $1 \mathrm{M} \mathrm{HCl}$ and rinsed with $10 \mathrm{ml}$ of $\mathrm{H}_{2} \mathrm{O}$. The amino acid fraction was eluted with $10 \mathrm{ml}$ of $10 \% \mathrm{NH}_{3}$. The eluate was freeze-dried and redissolved in $1.0 \mathrm{ml}$ of $0.1 \mathrm{M} \mathrm{HCl}$ before injection into a liquid chromatographic system.

All reagents used were ultra-pure HPLC grade. Deionized water was further purified with a Millipore Milli-Q LaboSystem ${ }^{\mathrm{TM}}$ and a Millipore Simpli Lab-UV ${ }^{\mathrm{TM}}$ (Japan Millipore Ltd., Tokyo, Japan) to remove both inorganic ions and organic

190 contaminants. All glassware was heated for 2 hours in high temperature oven (Yamato DR-22) at $500{ }^{\circ} \mathrm{C}$ in prior to use in order to eliminate any possible organic contaminants.

\section{Determination of hydrolyzed amino acids}

195 The concentration of THAA was determined with an ion-exchange HPLC system, which was composed of two high performance liquid chromatograph pumps (Shimadzu LC-6A), a cation exchange column (Shimpack ISC-07/S1504, $4 \mathrm{~mm}$ i.d. $\times 150 \mathrm{~mm}$ ), a post column derivatization system with $o$-phthalaldehyde (OPA) and $\mathrm{N}$-acetyl-L-cysteine (N-AcCys), and a Shimadzu RF-535 fluorometric detector (excited wavelength: $355 \mathrm{~nm}$ and emission wavelength: $435 \mathrm{~nm}$ ) (Kobayashi et al., 1991). The temperature of the column was maintained at $55{ }^{\circ} \mathrm{C}$. Gradient elution was performed by using the following eluents: A: $0.07 \mathrm{M}$ sodium citrate perchloric acid ( $\mathrm{pH}$ 3.20) with $7 \%$ ethanol, B: $0.2 \mathrm{M}$ sodium citrate boric acid- $\mathrm{NaOH}(\mathrm{pH} \mathrm{10).} \mathrm{The} \mathrm{flow} \mathrm{rate} \mathrm{of} \mathrm{the}$ carrier was $0.3 \mathrm{ml} / \mathrm{min}$. The amino acid standards, OPA and N-AcCys were obtained 
from WAKO Chemical Co.

\section{Separation of D- and L- enantiomer}

The determination of D- and L-amino acid enantiomers was achieved with an RP-HPLC system, which was composed of high performance liquid chromatograph pumps (Tosoh CCPM II), a reversed phase column (YMC-pack Pro C18 4.6 mm i.d. $\times$ $250 \mathrm{~mm}$ ), a precolumn derivatization system with OPA and N-AcCys, and a Tosoh FS 8020 detector (Takano et al., 2003a; Takano et al., 2003b). An aliquot of desalted and redissolved amino acid extract was mixed in a glass vial with OPA and N-AcCys. Then the derivatives were extracted by solid phase extraction with a TOYOPACK ODS

215 column to eliminate hydrophobic impurities. The extract was injected to the RP-HPLC system to separate amino acid enantiomers. Gradient elution was applied using the following eluents; A: $40 \mathrm{mM}$ sodium acetic acid buffer (pH 6.5), B: 100\% methanol. Gradient program was performed as follows: 10 min (Eluent B: $0 \%$ ) -25 min (Eluent B: $10 \%$ ) - 65 min (Eluent B: $20 \%$ ) 80 min (Eluent B: $20 \%$ ) - 85 min

220 (Eluent B: $40 \%$ ) - 115 min (Eluent B: $60 \%$ ) - 120 min (Eluent B: $80 \%$ ) - 135 min (Eluent B: $0 \%$ ) (Kudo et al., 2003).

\section{Result and discussion}

Vertical profiles of total hydrolyzed amino acids

225 Blank analysis of amino acids during laboratory handling gave trace levels of glycine. Figure 3 shows a typical chromatogram of the hydrolyzed amino acid composition of the APSK 10-1-01 sample. Seventeen kinds of protein and non-protein amino acids were quantitatively determined. The concentrations of amino acids in the sub-vent core samples at the three sites are summarized in Table 1. Glycine was the most abundant amino acid on the average, followed by alanine. The concentration of glycine ranged between 2.9 and $31.5 \mathrm{nmol} / \mathrm{g}$-rock. Other protein amino acids such as valine, aspartic acid and glutamic acid were also among the major constituents, as shown in Figure 4. The relative abundance of each amino acid did not vary significantly with depth.

235 Figure 5 shows the vertical distribution of THAA and the relative abundances of 
aspartic acid and $\beta$-alanine at the three sites. The THAA content was on the order of $10^{1}-10^{2} \mathrm{nmol} / \mathrm{g}$-rock for all samples.

Methionine is known to be highly susceptible to hydrolytic loss during acid hydrolysis. Therefore, the measured concentration of methionine in the sediments may

240 be more than the actual concentration. Histidine, an essential amino acid, could not be detected because the detection peak was obscured by the background after $49 \mathrm{~min}$ retention time.

Concentrations of total organic carbon (TOC) and total nitrogen (TN) in the core samples were in the order of $10^{1}$ to $10^{2} \mu \mathrm{g} \mathrm{C} / \mathrm{g}$-rock and $10^{1}$ to $10^{3} \mu \mathrm{g} \mathrm{N} / \mathrm{g}$-rock at 245 another hydrothermal area, respectively (Takano et al., 2004). Although the $\mathrm{C} / \mathrm{N}$ ratio for bacteria-inhabited hydrothermal vent environments is not known, the present values are noticeably rich in nitrogen. Fourier transform infrared (FT-IR) analysis of clay minerals in the core samples suggests that ammonium ions are present at interlayer sites (Marumo et al., 2002). Ammonia is present in hydrothermal fluid at concentrations 250 from 10 to $20 \mu \mathrm{M}$ and is an important source of nitrogen nutrition for the sub-vent ecosystem (Umeki et al., 2002). This trend is similar to the distribution of total amino acids, suggesting that the organic carbon and amino acids are derived from in situ organisms, viable and/or nonviable (Takano et al., 2004).

\section{Alteration of dicarboxylic amino acids to w-amino acids}

Non-protein amino acids such as $\beta$-alanine, $\gamma$-aminobutyric acid and $\delta$-aminovaleic acid were also detected as minor constituents in the core samples. Hydrothermal alteration may cause decomposition of protein amino acid via decarboxylation at the $\alpha$-carbon (Ratcriff et al., 1974), for example, aspartic acid and glutamic acid will alter to $\beta$-alanine and $\gamma$-aminobutyric acid. Although the coring sites were located in vigorous hydrothermal systems, the biogeochemical markers $\beta$-alanine and $\gamma$-aminobutyric acid were detected as minor constituents. The ratio of $\beta$-alanine to aspartic acid, $\beta$-ala/Asp, varied from 0.03 to 1.10 (mean 0.21), and the ratio of $\gamma$-aminobutyric acid to glutamic acid, $\gamma$-ABA/Glu, varied from 0.02 to 3.98 (mean 0.37).

265 The presence of $\beta$-alanine and $\gamma$-aminobutyric acid as even minor constituents is considered evidence of the existence of bioorganic compounds derived from deep-sea 
sub-vent microbial activity. An increase in the abundance of $\beta$-alanine and $\gamma$-aminobutyric acid with depth have been found in marine sediments from the Vema Fracture Zone at the Mid-Atlantic Ridge (Aizenshtat et al., 1973), in marine clays from

270 the Pacific Ocean (Schroeder and Bada, 1976), and in recent research conducted within the International Ocean Drilling Program (ODP) for sediment cores Leg 139 and 168 (Andersson et al., 2000). As $\beta$-alanine and $\gamma$-aminobutyric acid comprise only a minor percentage of the total amino acid content of living organisms, it has been proposed that the decomposition of aspartic acid and glutamic acid, respectively, are the most likely 275 source of $\beta$-alanine and $\gamma$-aminobutyric acid in marine sediments (Cowie and Hedges, 1992, 1994; Schroeder, 1975).

It is well known that organic matter including hydrolyzed amino acids becomes scarcer with depth in simple sedimentation in marine sea-floor environments (e.g. Andersson et al., 2000) and terrestrial environment (Takano et al., 2003b) by diagenetic 280 alteration. In a previous study (Takano et al., 2003b), total organic carbon (TOC), THAA, and the microbial cell density in terrestrial core samples were found to be greatest at the surface and to decrease rapidly with depth, with correlation coefficients (r) for TOC and THAA versus microbial cell density of 0.97 and 0.98 , respectively. As seen in Figure 5, however, variable concentrations of amino acids were observed in some middle parts of the core samples. In fact, the highest concentration of amino acids was observed not at the surface but in the sub-seafloor of unconsolidated volcanic sands and pumice fragments. This may be due to fluids that migrate upward from deeper levels in the sub-vent, supplying energy and organic compounds. The movement of hydrothermal fluid may form veins toward the seafloor and/or black smoker chimneys.

\section{Possibility of abiotic formation of amino acids}

Amino acids in extreme hydrothermal environments may have been formed abiotically. Since the pioneering experiment of Miller (1953) established on the idea of

295 chemical evolution, numerous laboratory experiments concerning the formation of biologically interesting organic compounds have been performed. Among these, amino acids were detected in the product of the Strecker-type reactions under 
supercritical hydrothermal water flow conditions simulating submarine hydrothermal systems (Islam et al., 2001). Oligomerization in a high-pressure and high-temperature

300 flow reactor (Imai et al., 1999; Alargov et al., 2001; Islam et al., 2003) have also been reported. Among the products of the Strecker-Type reaction, peculiar $\omega$-amino acids such as $\beta$-alanine, $\gamma$-aminobutyric acid, and $\delta$-aminovaleic acid were detected under high-temperature and high-pressure flow conditions (Islam et al., 2001). It has thus been convincingly demonstrated that $\omega$-amino acid analogs may be abiotic markers under hydrothermal conditions (Islam et al., 2003).

\section{Amino acids and microbial activities}

The lack of evidence of abiotically synthesized amino acids of $\omega$-amino acid specimens and the abiotic tendency of products support the existence of a vigorous subjacent microbial oasis, which extends the known terrestrial habitable zone (Takano et al., 2004). Since the discovery of hyperthermophilic microbial activity in hydrothermal fluids recovered from smoker vents on the East Pacific Rise, a number of anaerobic sulfur-dependent heterotrophic hyperthermophiles have been isolated from high-temperature and high-pressure environments such as terrestrial hot springs and

315 submarine hydrothermal systems. Most of the marine forms belong to the domain Archaea, with the exception of the genus Thermotoga (Jannasch et al., 1988). Heterotrophic organisms utilize a wide variety of organic compounds including carbohydrates, amino acids, organic acids, and alcohols as sole carbon and energy sources. Isolated hyperthermophilic heterotrophic archaea and the requisite amino

320 acid assemblages have been characterized experimentally (Hoaki et al., 1994). Among these, the genus Thermococcus has been grown on protein mixtures, casamino acids (amino acid components hydrolyzed by casein), and purified proteins (e.g. casein and glatin), but not on carbohydrates or organic acids (Hoaki et al., 1994). Most of the $\mathrm{S}_{0}$-dependent hyperthermophilic heterotrophs isolated from marine hydrothermal vents

325 require a complex proteinaceous substrate (e.g. Jannasch et al., 1988; Jannasch et al., 1992). Thus, microbacterial communities in hydrothermal areas favor not only free amino acid analogs but also combined proteinaceous substrate. This may indicate the consumption and reuse of the biological source of amino acids by subterranean 
microorganisms to form a habitable zone. As noted earlier, the correlation coefficients ( $r$ ) for TOC and THAA versus microbial cell density are 0.97 and 0.98 , respectively (Takano et al., 2003b). Therefore, the concentration of amino acids may be closely related to the distribution of deep-sea subterranean microbial activity.

\section{Stereochemistry of chiral amino acids}

335 Amino acids may be synthesized by hydrothermal abiotic processes based on a chemical evolution scenario (e.g. Yanagawa and Kobayashi, 1992; Islam et al., 2001). If the amino acids are formed abiotically, the $\mathrm{D} / \mathrm{L}$ ratio converges to 1.0 in laboratory experiments such as hydrothermal simulations (e.g. Yanagawa and Kobayashi, 1992) or primitive atmospheric simulations (e.g. Takano et al., 2001). However, amino acids associated with life, particularly those forming proteins, are only L-form. Hence, low $\mathrm{D} / \mathrm{L}$ ratios are considered good evidence of biological activity, and a negative correlation between microbial cell density and $\mathrm{D} / \mathrm{L}$ ratio has been preliminarily reported (Takano et al., 2003b).

As shown in Table 2, the D/L ratios of aspartic acid (Asp), glutamic acid (Glu) and

345 alanine (Ala) indicate that only slight racemization from L-form to D-form occurred in this environment. Among these three chiral amino acids, aspartic acid has the highest rate constant of racemization during diagenesis (Takano et al., 2003b). As mentioned earlier, a monotonic decrease in $\mathrm{L}$ content, indicating racemization to $\mathrm{D}$-form, has been observed in simple sedimentation environments due to diagenetic alteration (e.g. 350 Andersson et al., 2000: Takano et al., 2003b). As shown in Table 2, however, the D/L ratio in the present sub-vent environment is quite low on average. The highest $\mathrm{D} / \mathrm{L}$ ratio of aspartic acid at sites APSK 08, 09 and 10 was $0.11,0.08,0.12$, respectively. The $\mathrm{D} / \mathrm{L}$ ratio of aspartic acid, glutamic acid, and alanine varied from 0.00 to 0.12 (mean 0.04 ), 0.00 to 0.06 (mean 0.03 ), and 0.00 to 0.21 (mean 0.05 ), respectively. In some

355 parts of the sub-vent column, the $\mathrm{D} / \mathrm{L}$ ratios of glutamic acid and alanine were predominant over aspartic acid. In the abiotic formation of amino acids, the $\mathrm{D} / \mathrm{L}$ ratio of amino acids converges to 1.0 due to the formation of a racemic mixture (e.g. Yanagawa and Kobayashi, 1992; Takano et al., 2001). The large enantiomeric excess of L-form amino acids observed in the present study may indicate that the amino acids were 360 derived from biotic flux in the sub-vent biosphere. This implication becomes even 
stronger when considering previous reports that the racemization rate constant is higher under hot geothermal conditions (Bada, 1972). The $\mathrm{D} / \mathrm{L}$ ratio of amino acids in the present core samples therefore reflect microbiological activity, as well as hydrothermal water samples (Horiuchi et al., 2003).

In addition to hydrothermal racemization, the D-amino acids may also originate from peptidoglycans in bacterial cell walls (Nyberg et al., 2001). Peptidoglycans are a product of bacterial metabolism and the principal biochemical sources of D-amino acids. D-Ala and D-Glu are among the most common D-amino acids found in bacterial cell walls (Friedman, 1999). The low D/L ratio for aspartic acid, glutamic acid and alanine in the vertical profile may contain two origins of D-form amino acids: i) racemerized D-amino acids from protein L-form analogs, ii) minor composition, however, D-amino acids derived from microbial constituents such as bacterial cell walls.

\section{Temperature limit and microbial habitat}

375 The currently accepted thermal limit of life is $113{ }^{\circ} \mathrm{C}$ (Blochl et al., 1997), and although some proteins from hyperthermophiles are more active at high pressure (Bernhardt, 1984), high pressure does not increase the thermal stability of micromolecules. Many microbiologists seem willing to speculate that the maximum may be closer to $150^{\circ} \mathrm{C}$ (Deming and Baross, 1993). The recent discovery of a

380 microbe living at $121{ }^{\circ} \mathrm{C}$ has broken the established temperature limit and extended the zone of microbial habitable temperature (Kashefi and Lovley, 2003). It is interesting to note that approximately $10^{4}-10^{5}$ cell/ml of microbes were found in $308{ }^{\circ} \mathrm{C}$ hydrothermal fluid from the drill hole in the Suiyo hydrothermal area when the drill hole was cased with metal to block the infiltration of interstitial water (Maruyama et al.,

385 2001). The hydrothermal gradient zone may be such that optimum fluid temperatures for microbial life occur in the sub-vent habitable regions.

Microbial diversity and populations in a hydrothermal plume that was present inside the caldera of the Suiyo Seamount were investigated by performing a phylogenetic analysis of the 16S rRNA gene and by using fluorescence in situ hybridization (FISH)

390 (Sunamura et al., 2004). An indicator of turbidity, the vertical total cell count varied from $5.6 \times 10^{4}$ to $1.1 \times 10^{5}$ cells $/ \mathrm{ml}$. Not only the sub-vent environment but also the hydrothermal plume are habitable spaces for microbes. Thus, Suiyo Seamount caldera 
Takano et al., Organic Geochemistry, 35, 1105-1120 (2004).

has functioned as a natural continuous incubator for microbes in the deep-sea environment (Sunamura et al., 2004; Nakagawa et al., 2004).

395

\section{Conclusions}

This report presents three significant kinds of evidence of a deep-sea hydrothermal sub-vent biosphere. The first evidence is that two sensitive biochemical indicators, aspartic acid versus $\beta$-alanine and glutamic acid versus $\gamma$-aminobutyric acid, are consistent with a large microbial population. Low $\beta$-alanine and $\gamma$-aminobutyric acid contents and $\beta$-ala/Asp and $\gamma$-ABA/Glu ratios are indicative of relatively fresh organic matter and partial hydrothermal alteration. The lack of abiotically synthesized amino acids such as $\omega$-amino acid specimens supports the biological origins of the amino acids. The difference between deep-sea biogenic sediment and sub-vent core samples was clarified based on the trend of aspartic acid to $\beta$-alanine and glutamic acid to $\gamma$-aminobutyric acid.

The second line of evidence is that the $\mathrm{D} / \mathrm{L}$ ratios of chiral amino acids were quite low on average, indicating a biotic origin of the detected amino acids. An unexpected vertical distribution with large enantiomeric excesses of L-form amino acids supports

410 the existence of subterranean microbial activity.

Finally, the relation between the concentration of aliphatic amino acids and their carbon number was clearly different from experiments involving the abiotic formation of amino acids. This is strong evidence that the sampled sub-vent amino acids are derived from subterranean biogenic processes. The present findings reveal that 415 hydrothermal sub-vent regions are a previously unknown extreme-environment biosphere.

\section{Acknowledgement}

The authors express their sincere thanks to two anonymous reviewers and Prof. 420 Philip A. Meyers, for insightful reviewing, comments, and rapid editorial handling, which helped to improve the earlier version of the manuscript.

The authors would like to thank Mr, T. Ebashi, Institute for Marine Resources and Environment, National Institute for Advanced Industrial Science and Technology and 
Takano et al., Organic Geochemistry, 35, 1105-1120 (2004).

Mr. T. Kaneko, Ms. Y. Edazawa, Yokohama National University, for their experimental 425 help and reviewing discussion. The authors also appreciate the crew members of the operating team of benthic multi-coring system (BMS) during the Hakurei-Maru II cruise. We are grateful to all scientists who participated in the cruise. This research was funded by the Ministry of Education, Culture, Sports, Science and Technology of Japan through the Special Co-ordination Fund for the Archaean Park Project; an international research project on interaction between the sub-vent biosphere and the geo-environment. 


\section{References}

435 Alargov, K. D., Deguchi, S., Tsuji, K., and Horikoshi, K. 2001. Reaction behaviors of glycine under super- and subcritical water conditions. Origins Life Evol. Biosphere. 32, $1-12$.

Andersson, E., Simoneit, B. R. T., and Holm, N. G., 2000. Amino acid abundance and stereochemistry in hydrothermally altered sediments from the Juan de Fuca Ridge, northeastern Pacific Ocean. Appl. Geochem. 15, 1169-1190.

Aizenshtat, Z., Baedecker, M. J., and Kaplan, I. R., 1973. Distribution and diagenesis of organic compounds in JOIDES sediment from Gulf of Mexico and western Atlantic. Geochim. Cosmochim. Acta. 37, 1881-1989.

Bada, L. J., 1972. Kinetics of racemization of amino acids as a function of pH. J. Ame. Chem. Soc. 94, 1371-1373.

Bada, J. L. and Schroeder, R. A., 1975. Amino acid racemization reactions and their geochemical implications. Naturwissenschaften. 62, 71-79.

Bada, J. L., and Man, E. H., 1980. Amino acid diagenesis in Deep Sea Drilling Project cores: Kinetics and mechanisms of some reactions and their applications in geochronology and in the paleotemperature and heat flow determinations. Earth-Sci. Rev. 16, 21-55.

Bernhardt, G., 1984. Biomolecules are unstable under black smoker conditions, Naturwissenschaften. 71, 583-586.

Blochl E., Rachel R., Burggraf S., Hafenbradl D., Jannasch W. H., and Stetter O. K., 1997. Pyrolobus fumarii, gen. and sp. nov., represents a novel group of archaea, extending the upper temperature limit for life to $113^{\circ} \mathrm{C}$. Extremophiles. 1, 14-21.

Burdige, D. J., 2001. Dissolved organic matter in Chesapeake Bay sediment pore waters, Org. Geochem. 32, 487-505.

Burdige, D. J., and Martens, C. S., 1988. Biogeochemical cycling in an organic-rich coastal marine basin: 10. The role of amino acids in sedimentary carbon and nitrogen cycling. Geochim. Cosmochim. Acta. 52, 1571-1584.

Burdige, D. J., and Martens, C. S., 1990. Biogeochemical cycling in an organic-rich coastal marine basin: 11 . The sedimentary cycling of dissolved, free amino acids. 
Geochim. Cosmochim. Acta. 54, 3033-3052.

465 Corliss, J. B., Dymond, J., Gordon, L. I., Edmond, J. M., von Herzen, R. P., Ballard, R. D., Green, K. K., William, D., Bainbridge, A., Crane, K., and van Andel, T. H., 1979. Submarine thermal springs on the Galapagos Rift. Science. 203, 1073-1083.

Cowie, G. L., and Hedges, J. I., 1992. Sources and reactivities of amino acids in a coastal marine environment. Limnol. Oceanog. 37, 703-724.

470 Cowie, G. L., and Hedges, J. I., 1994. Biochemical indicators of diagenetic alteration in natural organic matter mixtures. Nature. 369, 304-307.

Cragg, B. A., and Parkes, R. J., 1994. Bacterial profiles in hydrothermally active deep sediment layers from Middle Valley (N. E. Pacific) Site 857 and 858. Proc.Ocean Drilling Prog. Sci. Result. 139, 509-516.

475 Degens, E. T., Reuter, J. H., and Shaw, K. N. F., 1964. Biochemical compounds in offshore Californian sediments and sea waters. Geochim. Cosmochim. Acta. 28, 45-66.

Deming, J. W., and Baross., J. A., 1993. Deep-sea smokers: Windows to a subsurface biosphere? Geochim. Cosmochim. Acta. 57, 3219-3230

480 Friedman, M., 1999. Chemistry, nutrition, and microbiology of D-amino acids. J. Agric. Food. Chem. 47, 3457-3479.

Fredrickson, J.K. and Fletcher, M. (Eds.), 2001. Subsurface Microbiology and Biogeochemistry, John Wiley \&Sons Ltd, Chichester, New York.

Gold, T., 1992. The deep, hot biosphere. Proc. Natl. Acad. Sci. USA. 89, 6045-6049.

485 Haberstroh, P. R., and Karl, D. M., 1989. Dissolved free amino acids in hydrothermal vent habitats of the Guaymas Basin. Geochim. Cosmochim. Acta. 53, 2937-2945.

Harada, N. and Handa, N., 1995. Amino acid chronology in the fossil planktonic foraminifera, Pulleniatina obliquiloculata from Pacific Ocean. Geophys. Res. Lett. 22, 2353-2356.

490 Henrichs, S. M., and Farrington J. W., 1979. Amino acids in interstitial waters of marine sediments. Nature. 279, 319-322.

Henrichs, S.M., and Farrington, J.W., 1987. Early diagenesis of amino acids and organic matter in two coastal marine sediments. Geochim. Cosmochim. Acta. 51, $1-15$.

495 Henrichs, S.M., Farrington, J.W., and Lee, C., 1984. Peru upwelling region sediments 
near 158S. 2. Dissolved free and total hydrolyzable amino acids. Limnol. Oceanog. 29, 20-34.

Hino, R., 1991. Crustal structure below the sea-floor around the Japan Islands. J. Geograph. 100, 583-595. (in Japanese with English Abstract).

500 Hoaki, T., Nishijima, M., Kato, M., Adachi, K., Mizobuchi, S., Hanzawa, N., and Maruyama, T., 1994. Growth requirements of hyperthermophilic sulfur-dependent heterotrophic archaea isolated from a shallow submarine geothermal system with reference to their essential amino acids. Appl. Envir. Microbiol. 60, 2898-2904.

Holm, N. G. (Ed.)., 1992. Marine hydrothermal systems and the origin of life-special issue. Origins Life Evol. Biosphere. 22, 1-242.

Horiuchi, T., Takano, Y., Kobayashi, K., Marumo, K., Ishibashi, J., Urabe, T., 2004. Amino acids in hydrothermal water samples obtained from deep-sea hydrothermal vents at Suiyo seamount, Izu-Bonin Arc, Pacific ocean. Org. Geochem. In press.

Horsfall, I. M., and Wolff, G. A., 1997. Hydrolysable amino acids in sediments from the Porcupine Abyssal Plain, northeast Atlantic Ocean. Org. Geochem. 26, 311-320.

Ikeuchi, K., Doi, N., Sakagawa, Y., Kamenosono, H., and Uchida, T. 1998. High temperature measurements in well WD-1A and the thermal structure of the Kakkonda geothermal system, Japan. Geothermics, 16, 480-596.

Ingmanson, D. E. and Dowler, M. J., 1980. Unique amino acid composition of Red Sea brine. Nature. 286, 51-52.

Imai, E., Honda, H., Hatori, H., Brack, A., and Matsuno, K., 1999. Elongation of Oligopeptides in a Simulated Submarine Hydrothermal System. Science. 283, 831-833.

Islam, M. N., Kaneko, T., and Kobayashi, K., 2001. Determination of amino acids formed in a supercritical water flow reactor simulating submarine hydrothermal systems. Anal. Sci. 17, 1631-1634.

Islam, M. N., Kaneko, T., and Kobayashi, K., 2003. Reaction of Amino Acids in a Supercritical Water-Flow Reactor Simulating Submarine Hydrothermal Systems. Bull. Chem. Soc. Jpn. 76, 1171-1178.

525 Jannasch, H. W., Huber R., Belkin S., and Stetter K. O., 1988a. Thermotoga neapolitana sp. nov. of the extremely thermophilic, eubacterial genus Thermotoga. Arch. Microbiol. 150, 103-104. 
Takano et al., Organic Geochemistry, 35, 1105-1120 (2004).

Jannasch, H. W., Wirsen, C. O., Molyneaux, S. J., and Langworthy, T. A., 1988b. Extremely thermophilic fermentative archaeabacteria of the genus Desulfurococcus from deep-sea hydrothermal vents. Appl. Envir. Microbiol. 54, 31203-31209.

Jannasch, H. W., Wirsen, C. O., Molyneaux, S. J., and Langworthy, T. A., 1992. Comparative Physiological Studies on Hyperthermophilic Archaea Isolated from Deep-Sea Hot Vents with Emphasis on Pyrococcus Strain GB-D. Appl. Envir. Microbiol. 58, 3472-3481.

Kawahata, H., and Ishizuka, T., 1989. Organic properties of sediments and amino acids in interstitial waters from the flank of the Costa Rica rift, Galapagos Spreading Center (ODP Sites 677 and 678). In: Becker, K., Sakai, H., Shipboard, Scientific Party (Eds.), Proceedings of the Ocean Drilling Program, Scientific Results, Vol. 111, Ocean Drilling Program, College Station, TX, pp. 215-225.

Kashefi, K., and Lovley, R. D., 2003. Extending the upper temperature limit for life. Science. 301, 934.

Kobayashi, K., Kaneko, T., Kobayashi, T., Hui, L., Tsuchiya, M., Saito, T., and Oshima, T., 1991. Analysis of products synthesized from simulated primitive planetary atmospheres. I. Amino Acids. Anal. Sci. 7, 921-924.

Kudo, J., Takano, Y., Kaneko, T., and Kobayashi, K., 2003. A pre-treatment method for determination of amino acids and their D/L ratios in soil samples. Bunseki Kagaku. 52, 35-40. (in Japanese with English Abstract)

Marumo, K., Ishii, K., and Noda, M., 2002. Seafloor hydrothermal alteration at Suiyo submarine volcano: geochemical and mineralogical characteristics. Japan Earth and Planetary Science Joint Meeting, B008-002.

Marumo, K., Urabe, T., and Nakashima, M., 2003. Geochemistry and mineralogy of the hydrothermal system at Suiyo Seamount. Japan Earth and Planetary Science Joint Meeting, B002-001.

Marumo, K., Urabe, T., Ebashi, T., and Nakashima, M. 2004. BMS drilling into active submarine hydrothermal field at Suiyo seamount, Izu-Bonin Arc, Economic Geology, submitted.

Maruyama, A., Sunamura, M., Higashi, Y., Ishibashi, J., Kakegawa, T., 2001. Preliminary report for NT 01-09 cruise, Proceeding for JAMSTEC 18th Shinkai 
Symposium. p.44 (in Japanese).

Miller, S. L., 1953. Production of amino acids under possible primitive earth condition. Science. 117, 528-529.

Nakagawa, T., Ishibashi, J., Maruyama, A., Yamanaka, T., Morimoto, Y., Kimura, H., Urabe, T., and Fukui, M. 2004, Analysis of dissimilatory sulfide reductase and 16S rRNA gene fragments from deep-sea hydrothermal sites of the Suiyo seamount, Izu-Bonin Arc, Western Pacific. Appl. Envir. Microbiol. 70, 393-403.

Nyberg, J., Csap, J., Malmgren, A. B., and Winter, A., 2001. Changes in the D- and L-content of aspartic acid, glutamic acid, and alanine in a scleractinian coral over the last 300 years. Org. Geochem. 32, 623-632

570 Parkes, R. J., Cragg, B. A., Bale, S. K., Getliff, J. M., Goodman, K., Rochelle, P. A., Fry, J. C., Weightman, A. J., and Harvey, S. M., 1994, Deep bacterial biosphere in Pacific ocean sediments. Nature. 371, 410-413.

Prier, D., 1992. In Molecular Biology and Biotechnology of Extremophiles (Eds. R. A. Herbert and R. J. Sharp), Blackie, Glasgow \& London. p.163.

575 Ratcliff, M. A., Jr., Medley, E. E., and Simmonds, P. G., 1974. Pyrolysis of amino acids. Mechanistic Considerations. J. Org. Chem. 39, 1481-149.

Rittenberg, S. C., Emery, K. O., Hulsemann, J., Degens, E. T., Fay, R. C., Reuter, J. H., Grady, J. R., Richardson, S. H., Bray, E. E., 1963. Biogeochemistry of sediments in experimental Mohole. J. Sed. Petrol. 33, 140-172.

580 Schroeder, R. A., 1975. Absence of $\beta$-alanine and $\gamma$-aminobutyric in cleaned foraminiferal shells: Implications for use as a chemical criterion to indicate removal of non-indigenous amino acid contaminants. Earth Planet. Sci. Lett. 25, 274-278.

Shimoyama, A., and Ponnamperuma, C., 1975. Organic material of recent Chesapeake Bay sediment. Geochem. J. 9, 85-95.

Silfer, J.A., Engel, M.H., and Macko, S.A., 1990. The effect of hydrothermal processes on the distribution and stereochemistry of amino acids in Recent Antarctic sediments. Appl. Geochem. 5, 159-167.

Sunamura, M., Higashi, Y., Miyako, C., Ishibashi, J., and Maruyama, A. 2004, Two bacteria phylotypes are predominant in the Suiyo seamount hydrothermal plume. Appl. Envir. Microbiol. 70, 1190-1198. 
Takano et al., Organic Geochemistry, 35, 1105-1120 (2004).

Takano, Y., Ushio, K., Masuda, H., Kaneko, T., Kobayashi, K., Takahashi, J., and Saito, T., 2001. Determination of organic compounds formed in simulated interstellar dust environment. Anal. Sci. 17, 1635-1638.

595 Takano, Y., Kaneko, T., Kobayashi, K., and Takahashi, J., 2002. Asymmetric Photolysis of (DL)-isovaline by Synchrotron Radiation. Origins Life Evol. Biosphere. 32, 447-448.

Takano, Y., Sato, R., Kaneko, T., and Kobayashi, K., 2003. Biological origins of amino acids in subterranean hydrothermal vent, Toyoha mine, Hokkaido, Japan. Org. Geochem. 34, 1491-1496.

Takano, Y., Kobayashi, K., Yamanaka, T., Marumo, K., and Urabe, T. 2004a. Amino acids in the $308^{\circ} \mathrm{C}$ deep-sea hydrothermal systems at Suiyo Seamount, Izu-Bonin Arc, Pacific Ocean. Earth and Planetary Science Letters, 219, 147-153.

Takano, Y., Kudo, J., Kaneko, T., Kobayashi, K., Kawasaki, Y., Ishikawa, Y., 2004b. 605 Distribution of amino acids and its stereo chemistry related with biological activities in Rikubetsu, Hokkaido, Japan. Geochem. J. 38, 153-161.

Tsunogai,U., Ishibashi, J., Wakita, H., Gamo, T., Watanabe, K., Kijimura, T., Kanayama, S., and Sakai, H., 1994. Peculiar features of Suiyo Seamount hydrothermal fluids, Izu-Bonin arc: Differences from subaerial volcanism. Earth $610 \quad$ Planet. Sci. Lett. 126, 289-301.

Umeki, Y., Ishibashi, J., Chiba, H., Yamanaka, T., Toki, T. 2002. Behaviors of nitrogen and sulfur in hydrothermal fluids fro Suiyo seamount, Izu-Bonin Arc, Japan Earth and Planetary Science Joint Meeting, B008-P012.

Urabe, T., Maruyama, A., Marumo, K., Seama, N., and Ishibashi, J., 2001. The 615 Archaean Park project update. Inter Ridge-Crest Res. 10, 23-25.

Urabe, T., Maruyama, A., Seama, N., Ishibashi, J., Marumo, K., and Kinoshita, M., 2003. How does the unique nature of the hydrothermal system within arc volcano affect the resultant sub-vent biosphere? Japan Earth and Planetary Science Joint Meeting, B002-001.

620 Yamanaka, T., Yokoo, Y and Urabe, T., 2001. Biogeochemical study of total fatty acid in surface sediment of Suiyo hydrothermal system, Japan Earth and Planetary Science Joint Meeting, Cm-002.

Yamanaka, T., and Sakata, S., 2004, Abundance and distribution of fatty acids in 
Takano et al., Organic Geochemistry, 35, 1105-1120 (2004).

hydrothermal vent sediments of the western Pacific Ocean. Org. Geochem. 35, 625 573-582.

Yanagawa, H. and Kobayashi, K., 1992. An experimental approach chemical evolution in submarine hydrothermal systems. Origins Life Evol. Biosphere. 22, 147-159.

Yuasa, M., Murakami, F., Saito, E., and Watanabe, K. 1991, Submarine topography of seamounts on the volcanic front on the Izu-Ogasawara, Bonin Arc. Bull. Geol. Surv. Jpn. 42, 703-743.

Yuasa, M., 1992. Origin of along-arc variations on the volcanic front of the Izu-Ogasawara-Bonin Arc. Bull. Geol. Surv. Jpn. 43, 457-466.

Watanabe, K., and Kajimura, T. 1991. The hydrothermal mineralization at Suiyo seamount, in the Izu-Ogasawara Arc. Resource Geology. 44, 133-140. (in Japanese with English abstract)

Watanabe, K., and Kajimura, T., 1993. Topography, geology and hydrothermal deposits at Suiyo Seamount, Proc. JAMSTEC Symp. Deep-Sea Res. Special Issue. 9, 77-89. (in Japanese with English Abstract)

Whelan, J. K., 1977. Amino acids in a surface sediment core of the Atlantic abyssal plain. Geochim. Cosmochim. Acta. 41, 803-810. 


\section{Figure and Table}

Figure 1 (a) Geological location of the Izu-Bonin Arc on the eastern edge of the Philippine Sea plate, western Pacific ocean. (b) Topographic map of the Suiyo seamount in the Shichiyo seamount chain (Cited from Tsunogai et al., 1994). Si = Suiyo Seamount; $O R=$ Ogasawara Ridge; $O T=$ Ogasawara Trough; $\mathrm{S}=$ Sofugan Island; $\mathrm{N}=$ Nichiyo Seamount; $\mathrm{G}=$ Getsuyo Smt.; $\mathrm{K}=$ Kayo Smt.; $\mathrm{M}=$ Mokuyo Smt.; Kn = Kinyo Smt.; $\mathrm{D}=$ Doyo Smt.; $N s=$ Nishinoshima Island. (c) Distribution of chimneys, mounds, and BMS drilling sites in the bottom of the caldera at Suiyo Seamount (Cited from Marumo et al., 2004)

Figure 2 The vertical variations in the mineral assemblages of the core samples. Cited and modified from Marumo et al., 2004.

655 Figure 3 Typical ion-exchanged chromatogram of hydrolyzed amino acids in deep-sea hydrothermal sub-vent core samples from APSK 10. Major constituents were protein amino acid analogs, with minor non-protein analogs. Asp = aspartic acid; Thr $=$ Threonine; Ser $=$ serine; Glu $=$ glutamic acid; $\alpha$-AAA $=\alpha$-aminoadipic acid; Gly = glycine; Ala = alanine; $\alpha-\mathrm{ABA}=\alpha$-aminobutyric acid; $\mathrm{Val}=$ valine; Met $=$ Methionine; Ile $=$ isoleucine; Leu $=$ leucine; Tyr $=$ tyrosine; Phe $=$ phenylalanine; $\beta$-Ala $=\beta$-alanine; $\gamma$-ABA $=\gamma$-aminobutyric acid.

Figure 4 Molar ratio of hydrolyzed amino acid in deep-sea hydrothermal sub-vent core samples at sites APSK 08, 09 and 10. Each marker indicates the individual amino acid component.

Figure 5 Vertical distribution of THAA and specific biogeochemical indicators in sub-vent core samples (a) APSK 08 (b) APSK 09 and (c) APSK 10. samples of APSK 08 at Suiyo seamount, Izu-bonin arc, Pacific ocean. The 
Takano et al., Organic Geochemistry, 35, 1105-1120 (2004).

maximum depth of the coring was $3,807 \mathrm{~mm}$ below sea floor where the hydrothermal fluid temperature was measured at $62.5^{\circ} \mathrm{C}$.

675 Table 2 Vertical concentration of amino acids in submarine hydrothermal sub-vent core samples of APSK 09 at Suiyo seamount, Izu-bonin arc, Pacific ocean. The maximum depth of the coring was $8,992 \mathrm{~mm}$ below sea floor where the hydrothermal fluid temperature could not measured by weather condition.

680 Table 3 Vertical concentration of amino acids in submarine hydrothermal sub-vent core samples of APSK 10 at Suiyo seamount, Izu-bonin arc, Pacific ocean. The maximum depth of the coring was $7,035 \mathrm{~mm}$ below sea floor where the hydrothermal fluid temperature was measured at $89.3{ }^{\circ} \mathrm{C}$.

685 Table 4 D/L ratio of aspartic acid (Asp), glutamic acid (Glu) and alanine (Ala) in the site of APSK 08 at Suiyo seamount, Izu-bonin arc, Pacfic ocean.

Table 5 D/L ratio of aspartic acid (Asp), glutamic acid (Glu) and alanine (Ala) in the site of APSK 09 at Suiyo seamount, Izu-bonin arc, Pacfic ocean.

690

Table $6 \mathrm{D} / \mathrm{L}$ ratio of aspartic acid (Asp), glutamic acid (Glu) and alanine (Ala) in the site of APSK 10 at Suiyo seamount, Izu-bonin arc, Pacfic ocean. 
Figure 1

(a)

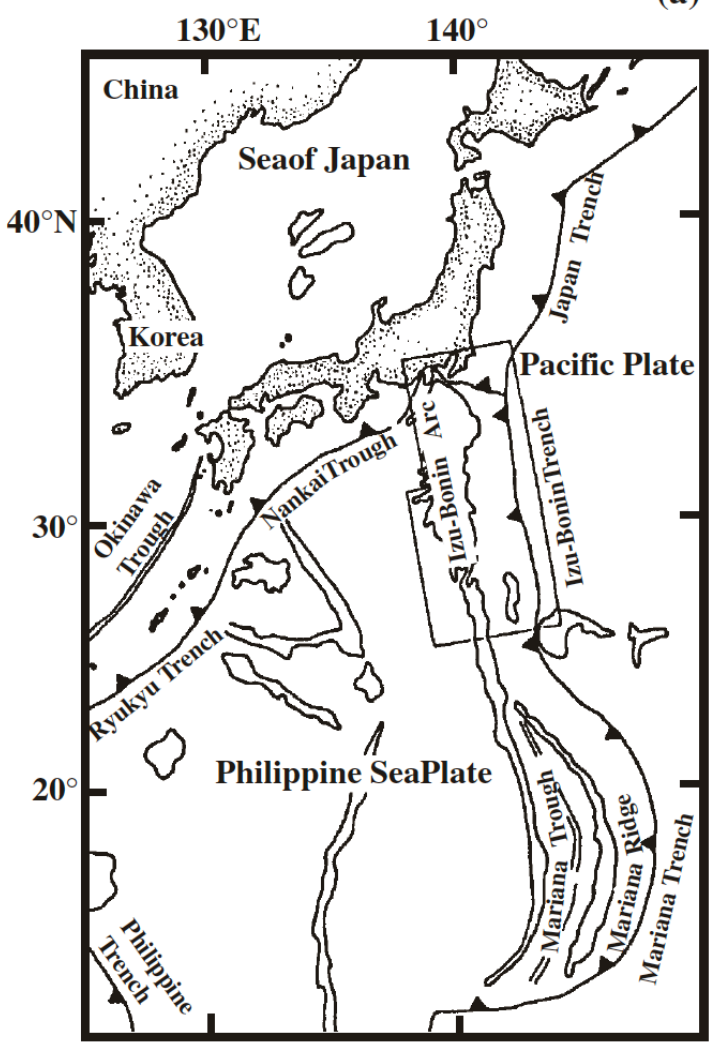

(b)

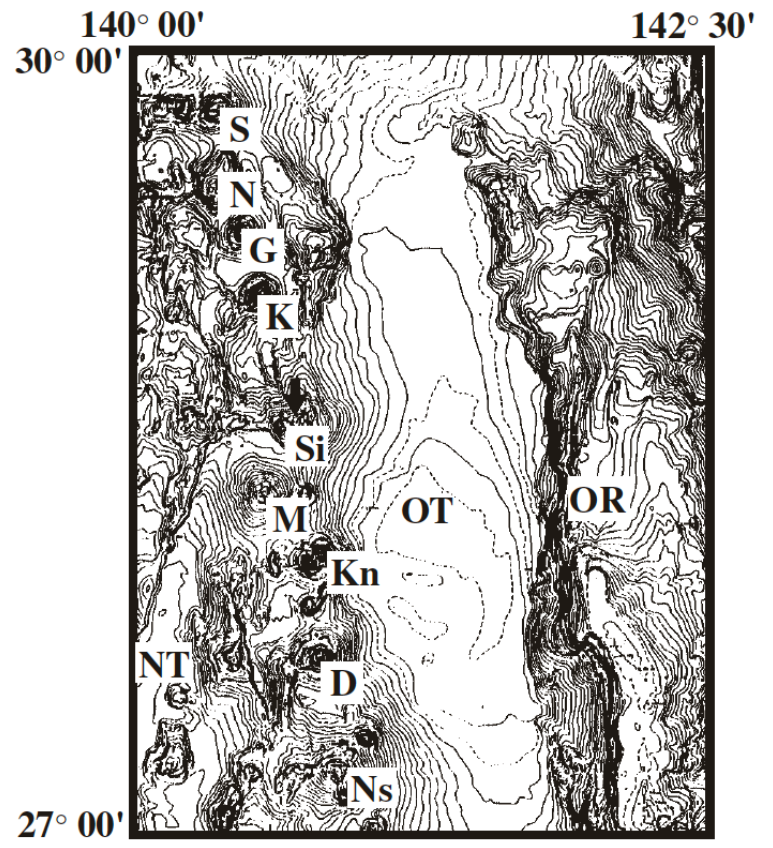

(continue to next page)

Figure 1

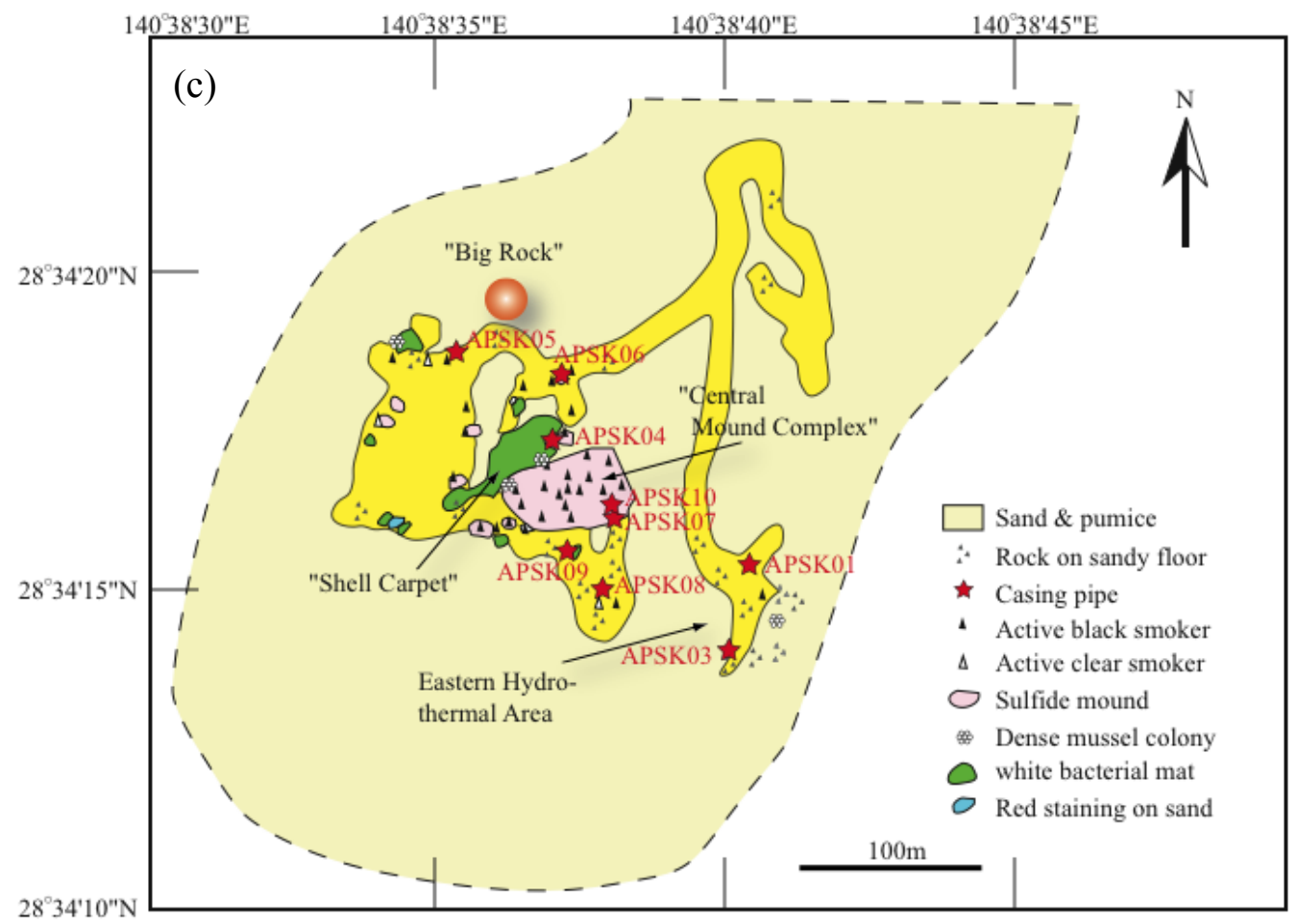


Figure 2
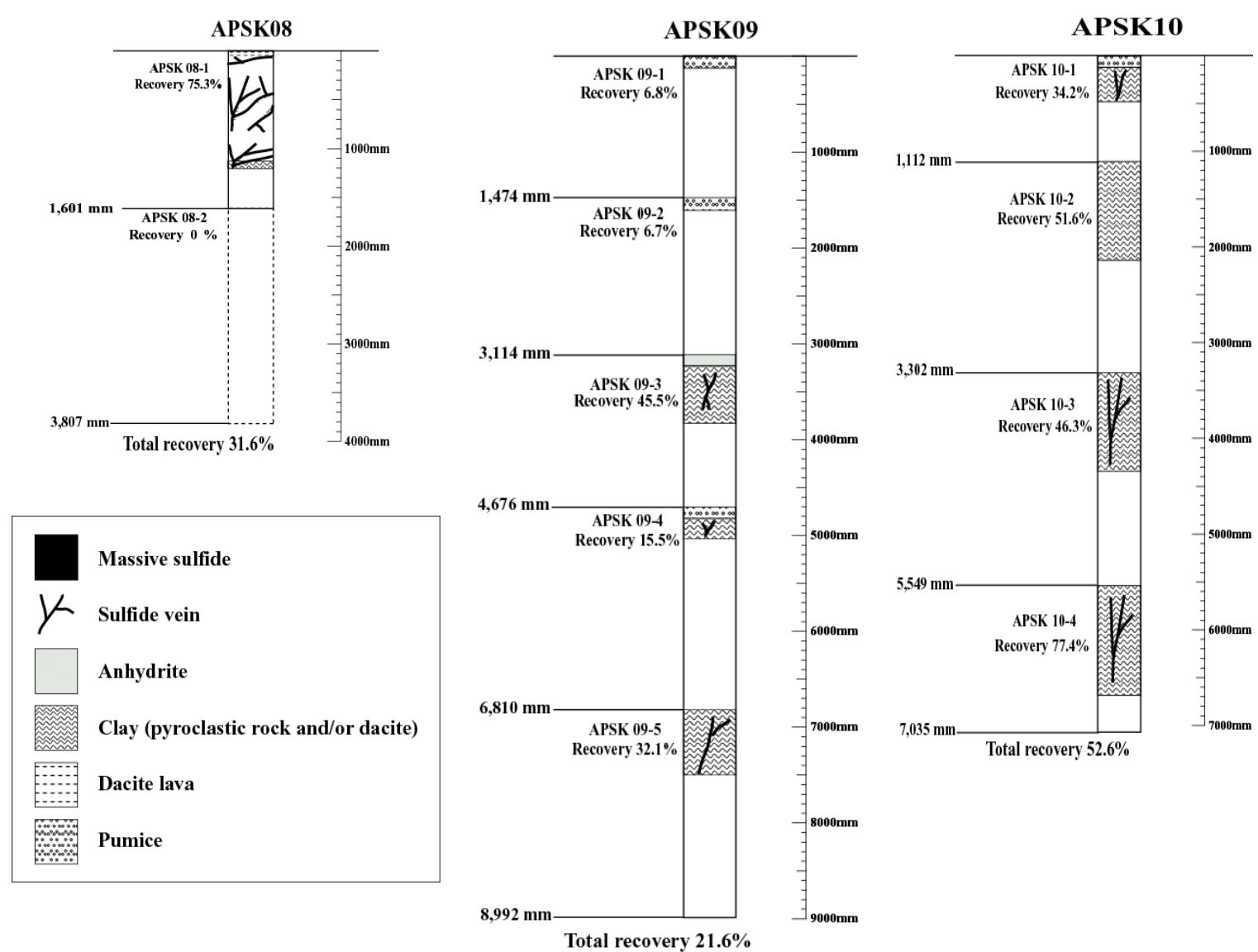

Figure 3

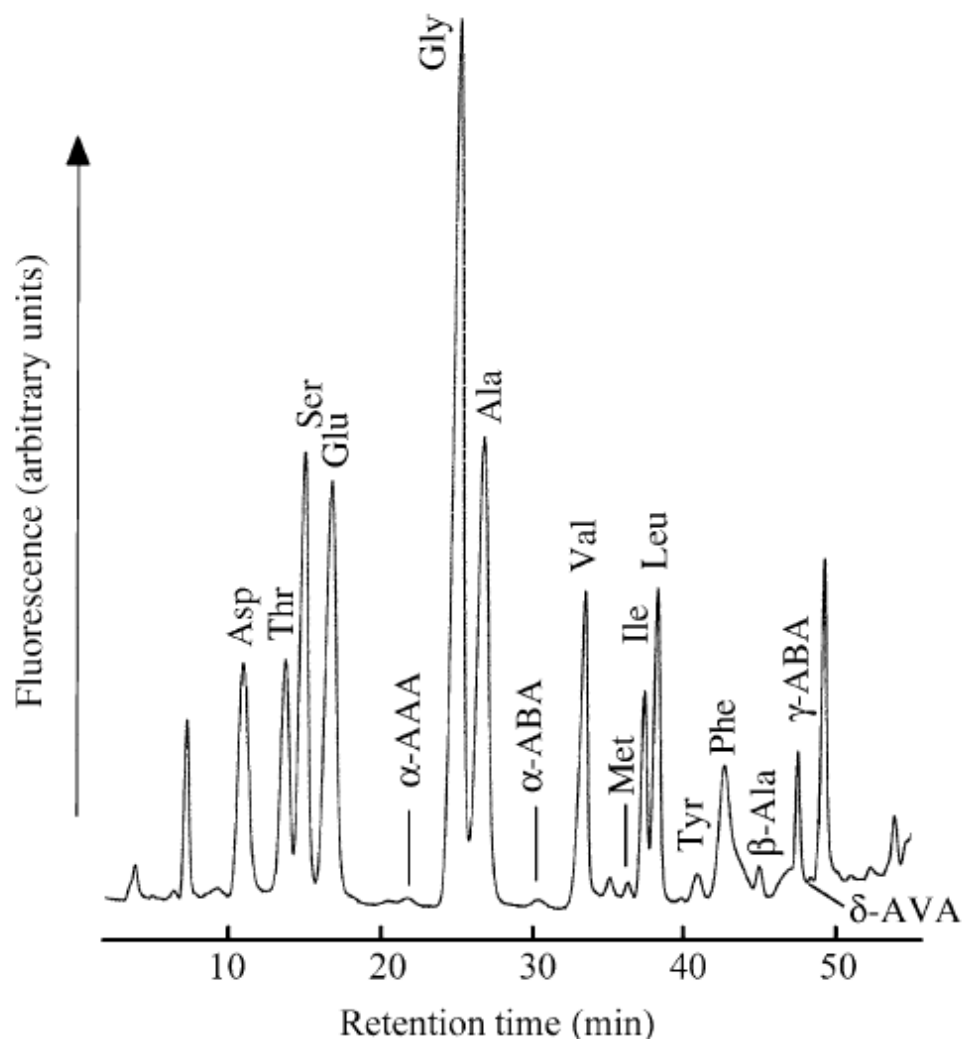




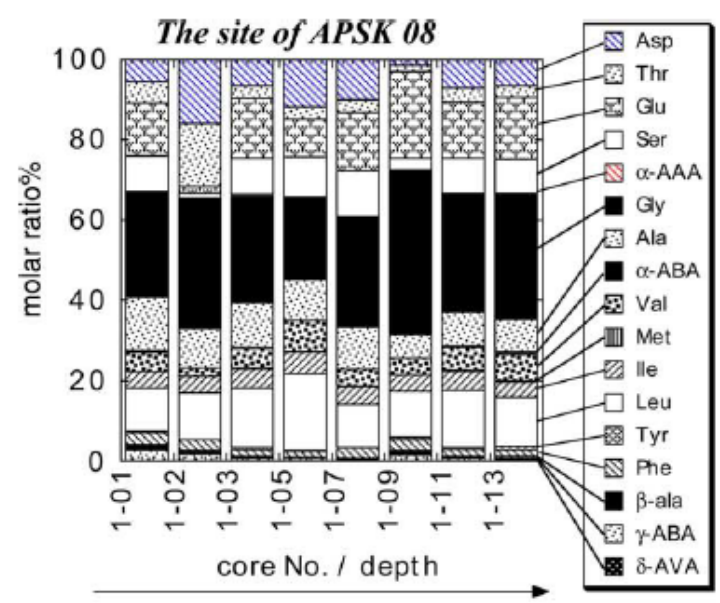

Figure 4

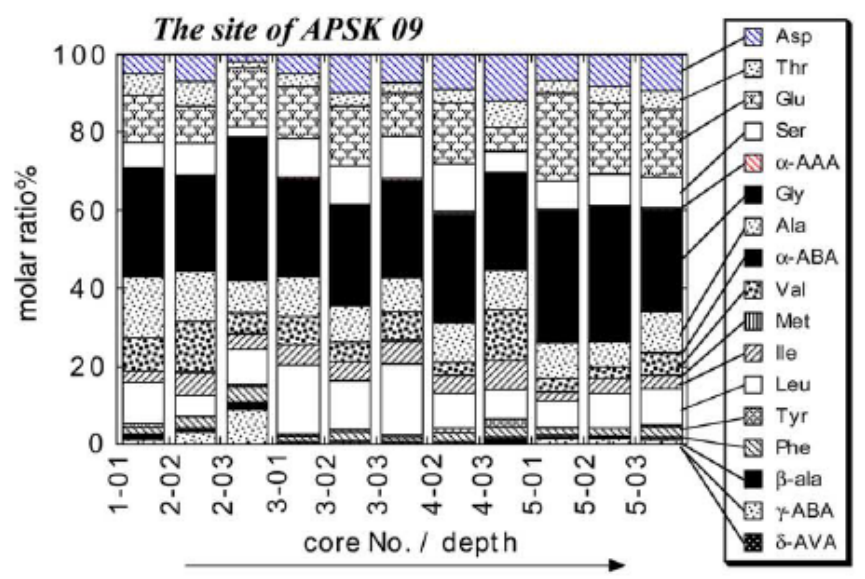

(continue to next page)

Figure 4

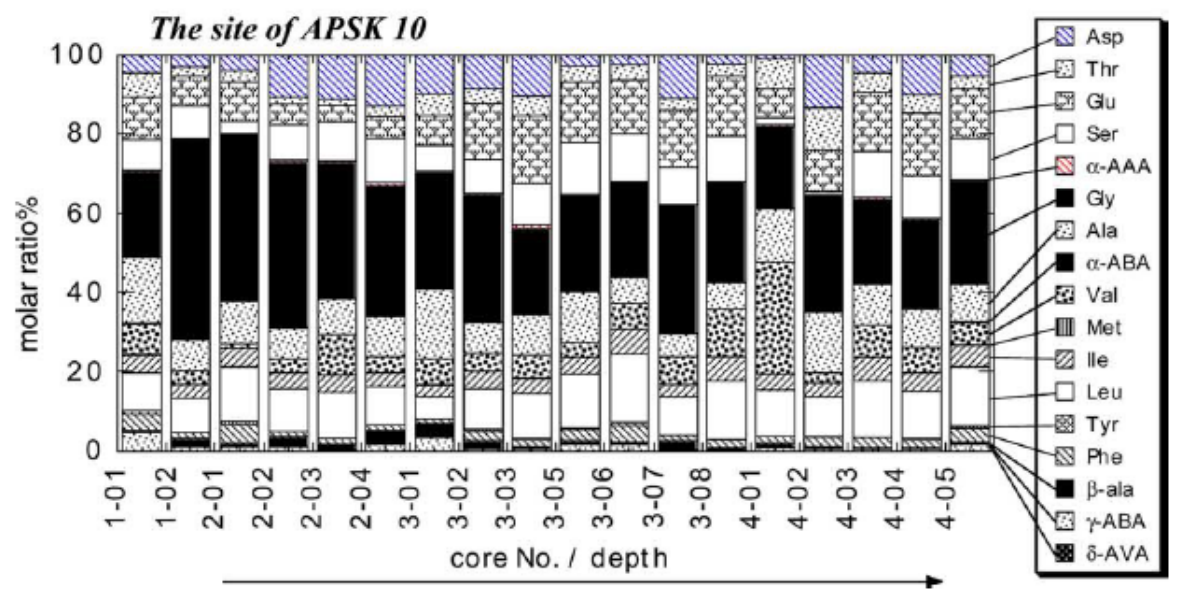


Figure 5

(a)

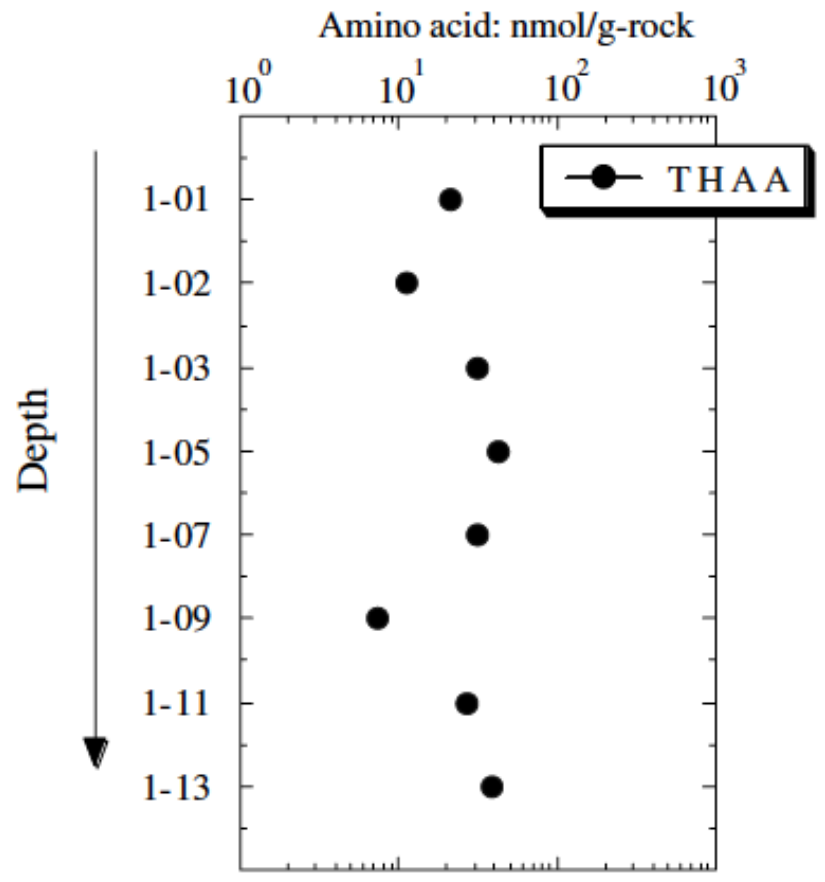

Depth / 3,807 mm mole\% of aspartic acid

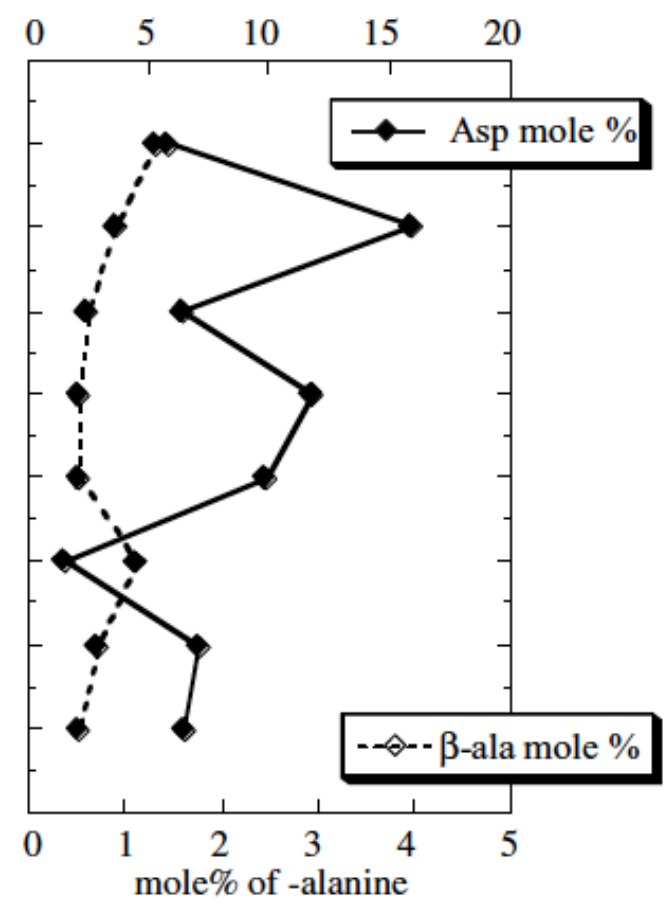

(continue to next page) (b)

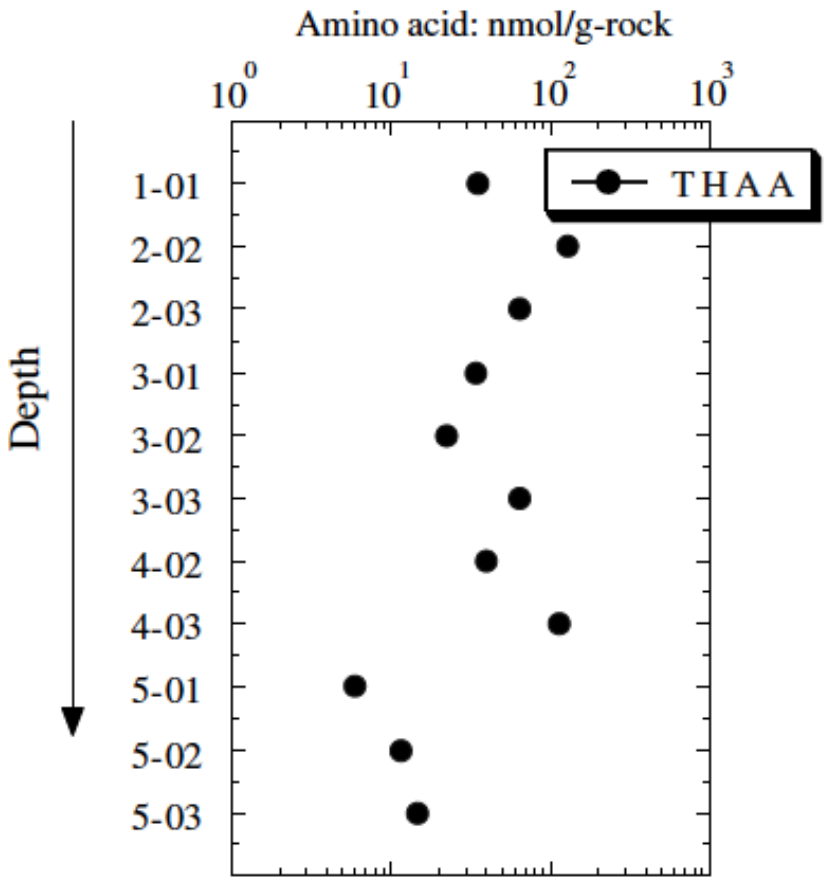

Depth / 8,992 mm mole $\%$ of aspartic acid

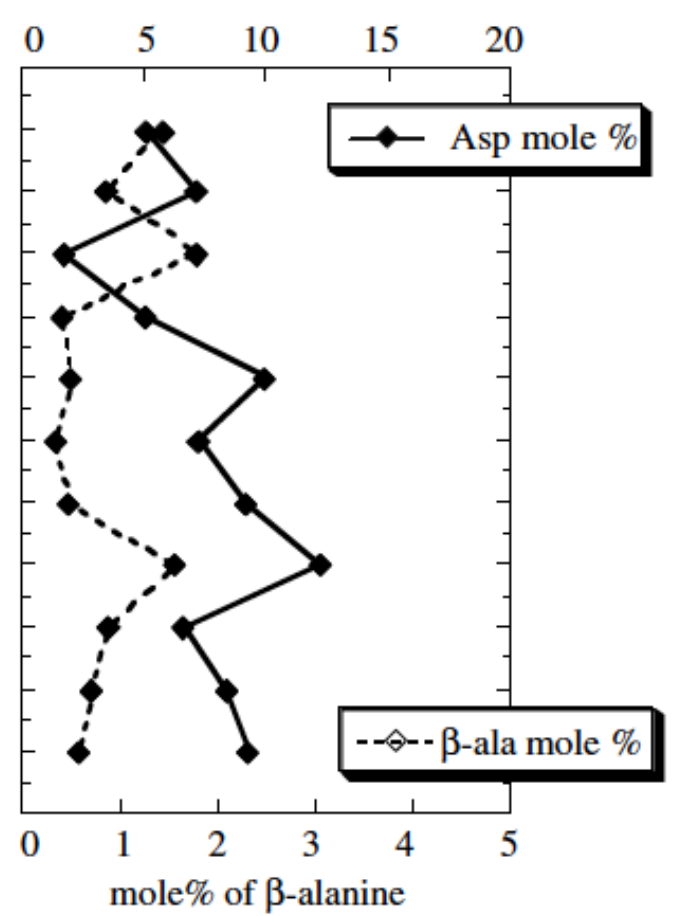


Figure 5

(c)

Amino acid: nmol/g-rock

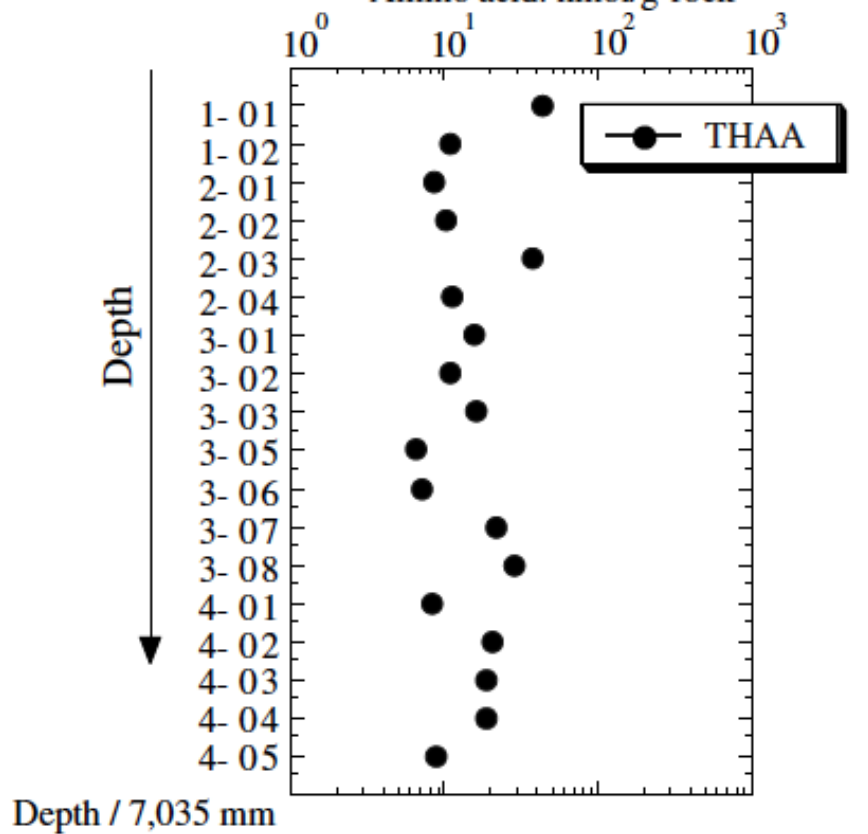

mole $\%$ of aspartic acid

Depth $/ 7,035 \mathrm{~mm}$

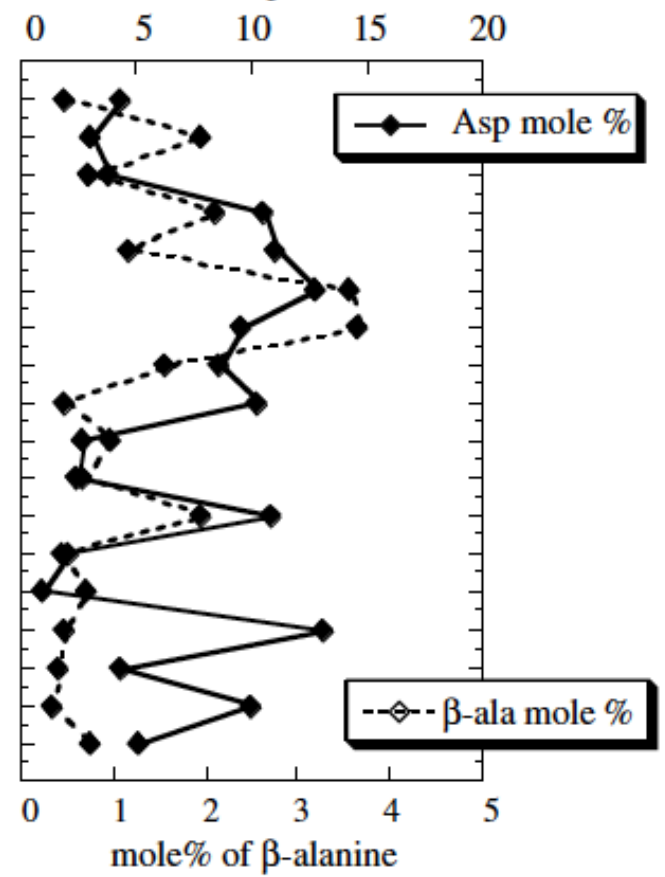

APSK08

Table 1

\begin{tabular}{ccccccccccccccccccccc}
\hline sample No. & Asp & Thr & Ser & Glu & $\alpha$-AAA & Gly & Ala & $\alpha$-ABA & Val & Met & Ile & Leu & Tyr & Phe & $\beta$-Ala $\gamma$-ABA & $\delta$-AVA & Total & \\
\hline $\mathbf{1 - 0 1}$ & 1.19 & 1.07 & 2.80 & 1.81 & n.d. & 5.51 & 2.82 & 0.08 & 1.05 & n.d. & 0.86 & 2.28 & 0.06 & 0.60 & 0.27 & 0.58 & tr. & $\mathbf{2 0 . 9 9}$ & \\
$\mathbf{1 - 0 2}$ & 1.78 & 1.79 & 0.19 & 0.12 & n.d. & 3.66 & 1.13 & n.d. & 0.21 & n.d. & 0.48 & 1.30 & 0.02 & 0.27 & 0.10 & 0.21 & tr. & $\mathbf{1 1 . 2 5}$ & \\
$\mathbf{1 - 0 3}$ & 1.94 & 1.06 & 4.58 & 2.76 & 0.06 & 8.22 & 3.45 & 0.09 & 1.48 & 0.10 & 1.44 & 4.64 & 0.15 & 0.47 & 0.19 & 0.17 & tr. & $\mathbf{3 0 . 7 9}$ \\
$\mathbf{1 - 0 5}$ & 4.93 & 1.35 & 3.95 & 4.21 & 0.09 & 8.59 & 4.37 & n.d. & 3.26 & 0.06 & 2.35 & 8.02 & 0.15 & 0.57 & 0.20 & 0.21 & tr. & $\mathbf{4 2 . 3}$ & n. \\
$\mathbf{1 - 0 7}$ & 3.08 & 1.08 & 4.55 & 3.67 & n.d. & 8.66 & 3.26 & n.d. & 1.39 & n.d. & 1.43 & 3.40 & n.d. & 0.76 & 0.15 & 0.08 & tr. & $\mathbf{3 1 . 5 1}$ \\
$\mathbf{1 - 0 9}$ & 0.10 & 0.11 & 1.57 & 0.21 & n.d. & 2.97 & 0.44 & n.d. & 0.31 & n.d. & 0.28 & 0.83 & 0.05 & 0.19 & 0.08 & 0.12 & tr. & $\mathbf{7 . 2 5}$ \\
$\mathbf{1 - 1 1}$ & 1.91 & 0.90 & 3.85 & 2.40 & n.d. & 7.98 & 2.24 & 0.09 & 1.60 & 0.06 & 1.33 & 3.81 & 0.12 & 0.44 & 0.18 & 0.16 & tr. & $\mathbf{2 7 . 0 8}$ \\
$\mathbf{1 - 1 3}$ & 2.45 & 1.15 & 5.85 & 3.32 & n.d. & 11.89 & 3.19 & 0.17 & 2.60 & 0.13 & 1.39 & 4.78 & 0.25 & 0.59 & 0.17 & 0.14 & 0.15 & $\mathbf{3 8 . 2 3}$
\end{tabular}

n.d.: not detected, tr.: trace amount (detected but not quantified) 


\begin{tabular}{|c|c|c|c|c|c|c|c|c|c|c|c|c|c|c|c|c|c|c|}
\hline sample No. & Asp & Thr & Ser & Glu & $\alpha$-AAA & Gly & Ala & $\alpha-\mathrm{ABA}$ & Val & Met & Ile & Leu & Tyr & Phe & $\beta$-Ala & $\gamma-\mathrm{ABA}$ & $\delta$-AVA & Total \\
\hline $1-01$ & 1.74 & 1.90 & 4.21 & 2.40 & n.d. & 9.67 & 5.59 & n.d. & 2.85 & n.d. & 1.08 & 3.78 & 0.25 & 0.60 & 0.50 & 0.46 & tr. & 35.04 \\
\hline 2-02 & 9.26 & 8.39 & 12.17 & 10.56 & 0.33 & 31.54 & 16.80 & 0.12 & 16.77 & 0.16 & 7.51 & 6.88 & 0.67 & 3.64 & 1.12 & 4.24 & tr. & 130.15 \\
\hline $2-03$ & 1.03 & 1.12 & 9.76 & 1.45 & 0.17 & 23.38 & 5.46 & n.d. & 3.43 & 0.10 & 2.46 & 5.58 & 0.40 & 2.63 & 1.14 & 5.77 & tr. & 63.89 \\
\hline 3-01 & 1.69 & 1.11 & 4.57 & 3.34 & 0.17 & 8.48 & 3.52 & n.d. & 2.40 & n.d. & 1.71 & 6.12 & 0.16 & 0.44 & 0.14 & 0.11 & tr. & 33.95 \\
\hline 3-02 & 2.21 & 0.81 & 3.42 & 2.18 & 0.07 & 5.77 & 2.09 & n.d. & 1.05 & n.d. & 1.15 & 2.83 & 0.10 & 0.51 & 0.11 & 0.11 & tr. & 22.42 \\
\hline 3-03 & 4.67 & 1.83 & 7.11 & 7.07 & 0.37 & 16.06 & 5.76 & n.d. & 4.77 & 0.06 & 3.75 & 11.96 & 0.26 & 0.80 & 0.22 & 0.17 & tr. & 64.84 \\
\hline 4-02 & 3.63 & 1.46 & 6.18 & 4.90 & 0.22 & 11.25 & 3.94 & n.d. & 1.39 & n.d. & 1.77 & 3.70 & 0.46 & 0.90 & 0.18 & 0.09 & tr. & 40.07 \\
\hline 4-03 & 13.80 & 8.03 & 6.81 & 6.39 & 0.17 & 28.13 & 11.50 & 0.15 & 14.52 & 0.09 & 8.75 & 8.66 & 2.33 & 3.01 & 1.77 & 0.12 & 0.07 & 114.23 \\
\hline 5-01 & 0.39 & 0.19 & 1.32 & 0.43 & n.d. & 2.00 & 0.53 & n.d. & 0.21 & n.d. & 0.14 & 0.39 & 0.02 & 0.10 & 0.05 & 0.09 & tr. & 5.87 \\
\hline 5-02 & 0.96 & 0.49 & 2.12 & 0.92 & n.d. & 4.02 & 0.76 & n.d. & 0.33 & n.d. & 0.46 & 1.02 & tr. & 0.24 & 0.08 & 0.17 & tr. & 11.55 \\
\hline $5-03$ & 1.37 & 0.76 & 2.57 & 1.15 & 0.06 & 3.90 & 1.55 & n.d. & 0.85 & n.d. & 0.51 & 1.40 & 0.07 & 0.39 & 0.08 & 0.19 & tr. & 14.84 \\
\hline
\end{tabular}

n.d.: not detected, tr.: trace amount (detected but not quantified)

\begin{tabular}{|c|c|c|c|c|c|c|c|c|c|c|c|c|c|c|c|c|c|c|}
\hline sample No. & Asp & Thr & Ser & Glu & $\alpha-\mathrm{AAA}$ & Gly & Ala & $\alpha-A B A$ & Val & Met & Ile & Leu & Tyr & Phe & $\beta$-Ala & $\gamma-\mathrm{ABA}$ & $\delta$-AVA & Total \\
\hline $1-01$ & 1.86 & 2.69 & 4.67 & 3.26 & 0.11 & 9.45 & 7.15 & 0.14 & 3.31 & 0.09 & 1.91 & 4.16 & 0.27 & 1.86 & 0.20 & 1.86 & 0.04 & 43.0 \\
\hline $1-02$ & 0.32 & 0.24 & 0.83 & 0.87 & 0.03 & 5.43 & 0.86 & n.d. & 0.37 & n.d. & 0.36 & 0.94 & n.d. & 0.16 & 0.21 & 0.12 & tr. & 10.7 \\
\hline 2-01 & 0.32 & 0.24 & 0.83 & 0.29 & n.d. & 3.56 & 0.89 & n.d. & 0.11 & n.d. & 0.40 & 1.14 & 0.08 & 0.39 & 0.06 & 0.10 & tr. & 8.4 \\
\hline $2-02$ & 1.07 & 0.18 & 0.56 & 0.90 & 0.06 & 4.30 & 0.83 & n.d. & 0.34 & n.d. & 0.43 & 1.11 & n.d. & 0.13 & 0.21 & 0.14 & tr. & 10.3 \\
\hline $2-03$ & 4.18 & 0.58 & 1.62 & 3.69 & 0.18 & 13.18 & 3.40 & n.d. & 3.86 & n.d. & 1.73 & 4.42 & n.d. & 0.52 & 0.43 & 0.16 & tr. & 37.9 \\
\hline 2-04 & 1.44 & 0.30 & 0.65 & 1.24 & 0.11 & 3.73 & 1.18 & n.d. & 0.46 & n.d. & 0.38 & 1.08 & 0.02 & 0.17 & 0.40 & 0.15 & tr. & 11.3 \\
\hline 3-01 & 1.46 & 0.87 & 1.15 & 1.01 & 0.04 & 4.56 & 2.73 & 0.02 & 1.00 & 0.02 & 0.45 & 0.86 & n.d. & 0.17 & 0.56 & 0.50 & tr. & 15.4 \\
\hline 3-02 & 0.92 & 0.37 & 1.56 & 0.92 & 0.04 & 3.49 & 0.87 & n.d. & 0.51 & n.d. & 0.44 & 1.13 & 0.06 & 0.26 & 0.17 & 0.08 & $\operatorname{tr}$. & 10.8 \\
\hline 3-03 & 1.65 & 0.79 & 2.77 & 1.74 & 0.12 & 3.54 & 1.63 & n.d. & 0.94 & n.d. & 0.63 & 1.81 & 0.06 & 0.26 & 0.07 & 0.10 & tr. & 16.1 \\
\hline 3-05 & 0.17 & 0.26 & 0.98 & 0.85 & n.d. & 1.61 & 0.84 & n.d. & 0.23 & n.d. & 0.27 & 0.90 & 0.02 & 0.19 & 0.06 & 0.09 & tr. & 6.5 \\
\hline $3-06$ & 0.17 & 0.26 & 0.98 & 0.84 & n.d. & 1.70 & 0.47 & n.d. & 0.47 & n.d. & 0.45 & 1.22 & 0.05 & 0.29 & 0.05 & 0.10 & tr. & 7.1 \\
\hline 3-07 & 2.36 & 0.61 & 3.22 & 2.04 & n.d. & 7.06 & 1.32 & n.d. & 1.50 & n.d. & 0.71 & 2.10 & n.d. & 0.33 & 0.42 & 0.06 & tr. & 21.7 \\
\hline 3-08 & 0.56 & 0.93 & 4.36 & 3.19 & n.d. & 7.40 & 1.85 & n.d. & 3.46 & n.d. & 1.71 & 4.25 & n.d. & 0.56 & 0.12 & 0.09 & tr. & 28.5 \\
\hline 4-01 & 0.07 & 0.62 & 0.60 & 0.15 & 0.05 & 1.70 & 1.11 & n.d. & 2.30 & n.d. & 0.35 & 0.94 & n.d. & 0.16 & 0.06 & 0.08 & tr. & 8.2 \\
\hline 4-02 & 2.65 & 2.20 & 2.12 & 0.16 & n.d. & 6.00 & 3.11 & n.d. & 0.51 & n.d. & 0.70 & 2.02 & 0.07 & 0.41 & 0.09 & 0.14 & tr. & 20.2 \\
\hline 4-03 & 0.79 & 0.93 & 2.78 & 2.14 & 0.09 & 3.95 & 1.93 & n.d. & 1.53 & 0.02 & 1.05 & 2.65 & 0.01 & 0.40 & 0.07 & 0.10 & tr. & 18.5 \\
\hline 4-04 & 1.89 & 0.91 & 2.96 & 2.04 & 0.07 & 4.33 & 1.84 & n.d. & 1.23 & n.d. & 0.85 & 2.31 & 0.03 & 0.34 & 0.06 & 0.11 & tr. & 19.0 \\
\hline 4-05 & 0.45 & 0.30 & 1.10 & 0.93 & n.d. & 2.33 & 0.85 & n.d. & 0.53 & n.d. & 0.50 & 1.32 & 0.04 & 0.31 & 0.07 & 0.12 & tr. & 8.8 \\
\hline
\end{tabular}

n.d.: not detected, tr.: trace amount (detected but not quantified) 


\begin{tabular}{cccc}
\hline & \multicolumn{3}{c}{ D/L ratio } \\
\cline { 2 - 4 } core & Asp & Glu & Ala \\
\hline $1-01$ & 0.02 & 0.02 & 0.12 \\
$1-02$ & 0.02 & 0.06 & 0.05 \\
$1-03$ & 0.02 & 0.06 & 0.05 \\
$1-05$ & 0.11 & 0.05 & 0.08 \\
$1-07$ & 0.00 & 0.00 & 0.00 \\
$1-09$ & 0.02 & 0.06 & 0.05 \\
$1-11$ & 0.09 & 0.05 & 0.08 \\
$1-13$ & 0.01 & 0.05 & 0.03 \\
\hline
\end{tabular}

\begin{tabular}{cccc}
\hline & \multicolumn{3}{c}{ D/L ratio } \\
\cline { 2 - 4 } core & Asp & Glu & Ala \\
\hline 1-01 & 0.00 & 0.01 & 0.02 \\
$2-02$ & 0.08 & 0.02 & 0.02 \\
$2-03$ & 0.04 & 0.04 & 0.02 \\
$3-01$ & 0.00 & 0.00 & 0.03 \\
$3-02$ & 0.04 & 0.04 & 0.05 \\
$3-03$ & 0.07 & 0.03 & 0.05 \\
$4-02$ & 0.02 & 0.00 & 0.11 \\
$4-03$ & 0.01 & 0.00 & 0.02 \\
$5-01$ & 0.01 & 0.01 & 0.00 \\
$5-02$ & 0.05 & 0.01 & 0.11 \\
$5-03$ & 0.00 & 0.01 & 0.03 \\
\hline
\end{tabular}




\begin{tabular}{lccc}
\hline & \multicolumn{3}{c}{ D/L ratio } \\
\cline { 2 - 4 } core & Asp & Glu & Ala \\
\hline 1-01 & 0.04 & 0.07 & 0.16 \\
$1-02$ & 0.00 & 0.00 & 0.00 \\
$2-01$ & 0.00 & 0.00 & 0.00 \\
$2-02$ & 0.12 & 0.00 & 0.00 \\
$2-03$ & 0.07 & 0.02 & 0.00 \\
$2-04$ & 0.02 & 0.00 & 0.00 \\
$3-01$ & 0.10 & 0.06 & 0.05 \\
$3-02$ & 0.05 & 0.01 & 0.00 \\
$3-03$ & 0.01 & 0.00 & 0.03 \\
$3-05$ & 0.03 & 0.06 & 0.05 \\
$3-06$ & 0.01 & 0.00 & 0.03 \\
$3-07$ & 0.01 & 0.00 & 0.03 \\
$3-08$ & 0.03 & 0.06 & 0.05 \\
$4-01$ & 0.02 & 0.00 & 0.00 \\
$4-02$ & 0.01 & 0.00 & 0.21 \\
$4-03$ & 0.11 & 0.02 & 0.16 \\
$4-04$ & 0.02 & 0.00 & 0.14 \\
$4-05$ & 0.02 & 0.00 & 0.00 \\
& & & \\
\hline & & &
\end{tabular}

